\title{
doispontos:
}

\section{Systemic theory, strong institutionalism and representative politics: another way to a radical democratic politics}

\author{
Leno Francisco Danner \\ leno_danner@yahoo.com.br \\ Universidade Federal de Rondônia, Porto Velho, RO, Brasil.
}

\begin{abstract}
Jürgen Habermas' theory of modernity, i.e. his understanding of the Western modernization as systemic institutional self-differentiation, self-referentiality and self-subsistence, and his conception of a juridical-political procedural paradigm based on such notion of modernization, I argue that the systemic theory concerning modernization leads to strong institutionalism and to depoliticization of the institutional structuration, legitimation and evolution. The basic characteristic of systemic theory, which is the institutional self-referentiality and self-subsistence regarding political praxis and social normativity, autonomizes social systems of justifying and organizing themselves according to an inclusive democratic political praxis and to a biding notion of social normativity, depoliticizing them. From here emerges a radical separation between systemic institutional dynamic and democratic political-normative praxis, between institutions and civil society, in that systemic institutions become independent and closed in relation to politics and social normativity, allowing only a representative political role to social movements and citizen initiatives, centralizing and monopolizing the institutional legitimation and the social evolution inside the very own institutions. A radical democratic political praxis which can face such strong institutionalism based on the systemic theory must politicize both the liberal's notion of Western modernization and its consequent strong institutionalism, refusing the systemic theory as epistemological-political basis to the foundation of the contemporary institutional constitution and legitimation. It signifies also the normative-political centrality of the civil society's arena, practices and social subjects as the platform to institutional grounding and evolution.
\end{abstract}

Key-Words: Systemic Theory; Strong Institutionalism; Political Representation; Democracy; Radicalness.

\section{Teoria sistêmica, institucionalismo forte e política representativa: outro caminho para uma política democrática radical}

Resumo: partindo da crítica a dois pontos teórico-políticos centrais na teoria da modernidade de Jürgen Habermas, a saber, sua noção de modernidade ocidental como autodiferenciação, autorreferencialidade e autossubsistência sistêmicas, e a sua concepção de um paradigma jurídico-político procedimental baseado em tal compreensão de modernidade, argumento que a teoria sistêmica relativa ao processo de modernização leva ao institucionalismo forte e à despolitização da estruturação, da legitimação e da evolução institucionais. A característica básica da teoria sistêmica, que consiste na autorreferencialidade e na autossubsistência institucionais frente à práxis política e à normatividade social, dispensa os sistemas sociais de justificarem-se e de organizarem-se com base em uma práxis política democrática inclusiva e em uma noção vinculante de normatividade social, despolitizando-os. Daqui emerge a radical separação entre a dinâmica institucional sistêmica e a práxis político-normativa democrática, entre instituições e sociedade civil, no sentido de que as instituições tornam-se independentes e fechadas em relação à política e à normatividade social, permitindo somente um papel político representativo aos movimentos sociais e às iniciativas cidadãs, e centralizando e monopolizando a legitimação institucional e a evolução social dentro das 
próprias instituições. Uma práxis política democrática radical, que enfrenta tal institucionalismo forte baseado na teoria sistêmica, deve politizar tanto a modernização ocidental de cunho liberal quanto seu consequente institucionalismo forte, recusando a teoria sistêmica enquanto a base epistemológico-política para a fundamentação da constituição e da legitimação institucionais contemporâneas. Isso também significa a centralidade político-normativa da arena, das práticas e dos sujeitos sociais da sociedade civil como a plataforma para a fundamentação e a evolução institucionais.

Palavras-Chave: Teoria Sistêmica; Institucionalismo; Representação Política; Democracia; Radicalidade.

\section{INTRODUCTION}

The starting point of that paper is the intrinsic linking among strong institutionalism, political parties and economic oligarchies based on the affirmation of a systemic understanding of the institutional structuration, legitimation and evolution. Systemic theory concerning institutions is the major tendency in contemporary political theory and even in terms of Realpolitik, and it signifies that institutions or social systems are a set of technical norms and practices streamlined by a self-referential and self-subsisting internal procedure, assumed by self-authorized technicians and political elites. Now, which is very important in the current political praxis is the centrality of institutional technical, formal, impartial and neutral analysis and action as the real core - both normative and political - of the democratic society and its evolution along the time. The paper's basic argument is that strong institutionalism is founded on a notion of institution as a neutral and impartial super-subject which monopolizes the guard and fomentation of the social normativity, as well as it centralizes the legitimation and the performing of social evolution as an institutional matter and way. Here appears the institutional closure concerning social movements and citizen initiatives, and therefore the strong institutionalism: institutions are a normative-political structure which is impartial and neutral regarding civil society's political subjects, what means that just the institutions and their proceduralism represent the effective arena and norms of a democratic constitution, so just by institutions and according to their internal procedures and legal actors the social evolution is legitimized and performed. Here, civil society's political subjects have only a secondary and representative role.

The aim of the paper is to reconstruct philosophically and even sociologically such linking between systemic theory and strong institutionalism. I argue that the connection between systemic theory and strong institutionalism leads directly or indirectly to the consolidation of a problematic triple consequence: (a) a notion of institutional autonomy concerning the social subjects, in that institutions are a set of impartial, neutral and very objective norms and procedures which allow fair representation and equal opportunities of participation for all social subjects, as if institutions were independent of these social subjects, their hegemony and struggles; (b) an affirmation of the institutional monopolization of the social normativity, in the sense that institutions (as impartial, neutral and very objective structures, norms and procedures) guard and foment it to all society, and not contrary; (c) an institutional closure regarding to a direct democracy and the centrality of political representation as the key of the democratic dynamic, based both on the institutional centralization of political arena, procedures and actors, and on the institutions' systemic self-referentiality in relation to civil society, its political subjects and social struggles. 
My first central argument against systemic theory is that political institutions and capitalist market have (in these systemic theories) the same logic (i.e. a self-referential and self-subsisting organization and dynamic), and here appear both the sense of institutions' closure and self-referential dynamic, and the political representation as the basic democratic praxis. Now, here emerges also the intrinsic linking among strong institutionalism, political parties and economic oligarchies that characterizes current democratic Realpolitik (and Brazilian democratic Realpolitik in particular): systemic institutions only can be accessed and performed by political-economic elites and their technicians, the same way that institutional logic (both of political institutions and of market) is autonomous and self-subsisting concerning the social normativity and civil society's political subjects, what means that such logic cannot be substituted or violated from outside by other actors or principles or logics (like social normativity). Systemic institutional logic can be performed only from inside and by authorized elites (political, economic and scientific elites, truly), not by common citizens and social movements. And at the last systemic institutional logic delimitates what politics can and cannot do in relation to market's constitutions and evolution: the social systems' self-referentiality and self-subsistence mean that each social system or institution is independent of other institutions, as a technical-logical, non-political and non-normative sphere. Because of this characteristic, institutions cannot be substituted or violated by other institutions. So democracy and social normativity have no place in the market, as they have only a weak place in the strong institutionalism.

My second central argument is that a radical democratic praxis that faces such linking among strong institutionalism, political parties and economic oligarchies must deny the systemic comprehension of the institutions or social systems in favor of a political and normative institutional constitution. Indeed, the starting point of a radical democratic political praxis is exactly the emphasis on the political structuration, legitimation and performance of political and economic institutions, what means the centrality both of the social struggles and civil society's political subjects as the effective normative-political basis for the institutional constitution, and of a strict normative-political dependence of political and economic institutions concerning those social struggles and civil society's political subjects (as social classes). In both cases, therefore, a radical democratic political praxis confronts systemic institutional closure, self-subsistence and self-referentiality in relation to social normativity and to an inclusive democratic political praxis, denying the institutional independence regarding politics and substituting a technicallogical institutional grounding as basis of the systemic institutional constitution by an inclusive political praxis based on the political institutional structuration and on the intrinsic linking between political and economic fields. So, as consequence, representation founded on the systemic comprehension of institutions is overcome by an inclusive democratic praxis that frames institutions from a conception of social normativity which is very political, non-systemic, which is very normative, non-technical.

\section{SYSTEMIC THEORY AND POLITICAL PRAXIS: THE JÜRGEN HABERMAS' THEORY OF MODERNITY}

Many contemporary political theories have a notion of modernization that is characterized by the systemic self-differentiation, self-referentiality and self-subsistence, in that modernity's emergence and development signify the consolidation of different and autonomous institutions which monopolize specific fields of social evolution (see WEBER, 1984, 1992; PARSONS, 2010A, 2010B; HAYEK, 1987, 1995; NOZICK, 1991; HABERMAS, 1990, 1999, 2012A, 2012B; GIDDENS, 1996, 2000, 2001). 
Each one of these institutions has a very proper logic of functioning which is, as I said above, totally particular, self-referential and self-subsisting in relation to other social systems or institutions. Now, what is a social system or institution, according to contemporary political theories? What means the fact that a social system monopolizes a specific field of social evolution, becoming the very own field that it represents? A social system or institution is a set of rules, practices and procedures that ensembles and delimitates the legitimation and functioning of specific social fields as particular social fields, i.e. as social fields which have (each one) a proper identity that is not similar to other institutions or social systems. In other words, each social system has a very essential dynamic (legitimation, procedures, norms, actors) which at the same time identifies and differentiates it concerning the social world and other institutions. Such essential dynamic gives it specificity and constitutes a barrier which cannot be violated or crossed by other institutions, social dynamics and political subjects. So, in a systemic perspective, only from inside, a social system or institution can be understood, legitimized and performed. Any movement from outside is delegitimized by systemic institutions, because it destroys the institution's very own and particular, self-referential and self-subsisting logic of programming and functioning.

That is, according to those philosophical-sociological theories, the very basic characteristic of the Western modernization. Different of traditional social worlds, which have a very profound imbrication among nature, society and individuality, Western modernization is directly defined by the strong separation among them. So, traditional societies, based on such intrinsic linking, have two important characteristics that differentiate them of modern societies: they have no social mobility and criticism, because society and its relations are naturalized ones, at the same time that the individuals are subsumed by that naturalization of society; and they have a strict dependence and connection among politics, economy and culture, in that all social dynamic and even all particular relations are linked into a normative totality and founded on it. That last traditional characteristic means the fact that traditional world is basically a normative world, i.e. all of its relations are based on an ethical justification which is non-technical, non-measurable scientifically. Therefore, the connection among politics, culture and economy signifies that it is not possible to separate and to individualize such areas in the traditional societies (as those areas have not an individual logic of functioning, because they are absolutely linked in the social totality), and the understanding of a particular field of a traditional society implies the comprehension of the relational totality from which that sphere is part of (cf.: HABERMAS, 1999, p. 51;2012a, p. 140-141). Now, the emergence and development of the Western modernization assume a correlative double distinction regarding traditional societies.

We can see the Western modernization's specificity in the Jürgen Habermas' theory of modernity, which is my epistemological-political basis of analysis from now on. According to Habermas, European modernity (that is his model of philosophical-sociological analysis) arises as a double and imbricated process which differentiates it in relation to traditional societies, namely: the progressive consolidation of a secular and individualistic culture that leads to the radical separation between nature, society or culture and individuality (Cartesian distinction between res cogitans and res extensa expresses such modern specificity exemplarily); and because of that, the separation between politics (power), culture (social normativity) and economy (money). On the first case, European cultural modernity is characterized by secularism and individual rights, which become the epistemological, political and cultural basis to the foundation of a notion of social normativity or universalism (lifeworld, in Habermasian terms); on the second case, each field of social reproduction becomes independent, autonomous and selfreferential regarding other social fields (as we can see in modern liberal philosophies). So European 
cultural modernity is marked at the same time by the institutional secularization and individualism, which submit all institutional constitution, legitimation and evolution to normative-political criteriasocial normativity (based on secularism and individualism) is the condition to the political-economic modernization, i.e. to the development of modern State and capitalist market; on the other hand, modern State (bureaucratic power) and capitalist market (money) have very proper and closed logics of functioning which cannot be substituted by social normativity and political spontaneity - power and money, in the systemic theories, are not political or normative ones, but technical-logical instances and instruments (see HABERMAS, 2012a, p. 227, p. 383-384, p. 590-591).

From here Habermas constructs a distinction between a notion of cultural modernity and a notion of political-economic modernization: on the first case, we have, as I said above, the comprehension and the stylization of an European culture based on secularism and individualism, which eliminates the society's naturalization and generates the social criticism - that is the origin of the Habermasian critical theory's social normativity or epistemological-moral universalism (discourse ethics, communicative action, lifeworld); on the second case, political-economic modernization, founded on denaturalization of society favored by European cultural modernity, is characterized by the separation among culture, politics and economy, in the sense that society is not anymore a totality dependent exclusively of the social normativity and of the political praxis, as all of its fields (and particularly politics and economy) become self-referential and self-subsisting concerning their proper structuration and legitimation. Here emerges the specificity of the political-economic modernization: bureaucratic political power and money have very proper logics of functioning which cannot be equivalent and framed by cultural modernity's social normativity. On the one hand, therefore, cultural modernity submits all institutions to normative claims (or at least it tries to do that); on the other hand, political power and money are closed fields of action that do not depend of social normativity and political justifications to their evolution along the time: it is enough to appeal to their essential dynamics, to their self-referentiality and self-subsistence - and such appeal denies immediately normative claims and political praxis inside those social fields (see HABERMAS, 1999, p. 40-41; 1990, p. 13-14; 1997, p. 122, p. 143-144, p. 163; 2012a, p. 683; 2012b, p. 278, p. 330-331). It is sufficient to systemic institutions (as power and money, technocracy and laissez-faire or economicism) a technical-logical structuration and legitimation which is allowed exclusively from their internal technical-logical field, practices, procedures, codes and legal staff.

Now, the specificity of bureaucratic political power (modern State) and money (capitalist market) is at the same time to be and not to be part of the social world, and then to be and not be linked to cultural modernity's social normativity. They are part of the social because of their dependence of political obedience and labor (besides their necessity for human and natural resources, of course!); they are not part of the social because of their specific technical-formal logics of constitution and functioning, which are different of the normative constitution of the social. Then, bureaucratic political power and money submit lifeworld under their systemic imperatives, at the same time that they close themselves to society's normative claims, political praxis and cultural integrity. That is the modernity's beauty and tragedy, according to Jürgen Habermas. Cultural modernity is very explosive and it puts down conservative traditionalism (and Habermas understands traditionalism as a conservative social-cultural world), but modern State and capitalist market, conceived from a systemic comprehension, are not directly linked to and dependent of the social normativity, nor determined by them. As consequence, State's and market's development have the specificity of to be based on a very proper technical logic of functioning and legitimation that ignores strongly normative social claims and an inclusive democratic 
praxis, as well as such systemic logic consumes social forces and resources as condition to its subsistence while a private and closed logic and technic - here emerge modern pathologies caused by systemic institutions which submit and colonize the lifeworld's normative constitution by means of the technical dynamics of exploitation and legitimation (see HABERMAS, 2012b, p. 355, p. 551).

Now, the natural way for the resolution of that problem is, of course, the normative and democratic control of State and market, in that the social normativity and an inclusive democratic political praxis deny State's and Market's systemic constitution characterized by self-referentiality and self-subsistence concerning cultural modernity, substituting such institutional systemic comprehension and organization by normative justification and inclusive political participation. But Habermas said "no"! It is not possible to substitute systemic institutional constitution and legitimation by a direct democracy based on a notion of social normativity. Institutions' systemic constitution and legitimation must be respected. Why? Because of the institutional systemic constitution which does not admit a direct normative and political intervention - that is, Habermas continues, the Western modernization (systemic institutional self-differentiation, self-referentiality and self-subsistence) (see HABERMAS, 2003a, p. 61, p. 190; 2003b, p. 106). Indeed, Habermas' distinction between cultural modernity and political-economic modernity implies on the contraposition between normativity (and here democratic political praxis) and systemic institutions, in that each one of them has a very specific way of constitution, organization and legitimation. As consequence, a very acute contradiction between, on a side, democracy and, on the other side, State and market rationality is consolidated inside society, determining the weakening both of a critical social theory and of an emancipatory political praxis. Such contradiction means that democracy, based on a notion of social normativity and on an inclusive democratic political praxis, has not capability to frame and to substitute from outside systemic institutional dynamics, mechanisms and legal actors. Truly, a realistic analysis of Habermas' theory of modernity must conclude that democracy has no place inside systemic institutions, because of their technical and logical constitution and evolution, whose finality is the subsistence of the very own systemic organization along the time beyond social normativity and political praxis, i.e. beyond a democratic constitution and legitimation of State and capitalist market.

Therefore, we must distinguish in the Habermas' theory of modernity a double dynamic concerning social constitution, legitimation and evolution: on the one hand, social normativity and spontaneous political praxis, i.e. informal spheres, practices and political subjects from civil society; on the other hand, systemic institutional dynamic and logic, i.e. formal spheres, practices and legal actors (see HABERMAS, 2012a, p. 592; 2003a, p. 22; 2003b, p. 99). And we must be clear that in the Habermasian theory, the modernity emerges and develops itself because of the social normativity - because of the cultural modernity. Systemic institutional differentiation is a consequence of that, not contrary (see HABERMAS, 2012a, p. 590-591, p. 685). Besides we must be aware also of the fact that modern pathologies are caused by systemic institutional colonization (by bureaucratic power and money) of the normative and spontaneous lifeworld's constitution and legitimation (see HABERMAS, 2012b, p. 330-331, p. 355). So if we are aware of these two starting points of Habermas' theory of modernity, we certainly won't understand why social normativity and democratic political praxis cannot substitute or intervene from outside in the systemic institutional constitution and legitimation (after all it is exactly the systemic colonization of the lifeworld the cause of modern pathologies, such as poverty, marginalization, exploitation, technocracy, political formalism etc.). It has no sense to situate systemic institutional dynamic inside the social normativity and democratic political praxis (which could mean 
that systemic institutional dynamic is subordinated to and dependent of the social normativity), but at the same time affirm that the systemic constitution is self-referential and self-subsisting concerning the normative and political constitution of the lifeworld (therefore, the systemic institutional constitution and legitimation are basically an internal and institutionalized procedure, non-normative and nonpolitical).

A double problematic and correlative consequence arises of the Habermasian contraposition between social normativity and systemic institutional logic: the centrality of systemic institutional logic, dynamic and proceduralism concerning institutions' structuration, legitimation and evolution; and the indirect political intervention regarding social systems (especially capitalist market) which means the weakening of the political praxis as the basis of the societal and institutional life and action, or even the end of the political praxis as a basis of the societal and institutional constitution, legitimation and evolution. Indeed, the very first and basic point of consideration regarding institutions' structuration, legitimation and evolution is the fact that they have an exclusive, autonomous and self-referential dynamic and logic of programming and functioning. It means that institutions are an end-in-itself (at least in a strong way) and their dynamics and foundations are basically internal to the very own institutions. In first place, therefore, institutions' dynamic and validation are a monopoly of the institutions themselves, as well as such institutions centralize internally procedures, norms and practices which serve to structure and legitimize internal and external institutional functioning and relations. So in second place, institutions, according to systemic theories, become self-subsisting in relation to external contexts, i.e. they have an internal dynamic that is capable to ground and develop itself along the time, independently of those external contexts. In a such case, systemic institutions represent a complete and self-sufficient technical world, whose norms, practices, procedures and actors can sustain and evolve themselves from inside to the very own institution which they represent. I said technical world as representing systemic institutions because of the fact that such kind of institutional understanding conceives institutions' structuration, legitimation and evolution as a logical and technical procedure, made by technical-legal staff based on technical-legal norms and practices.

Let's take an example. Capitalist market must be conceived, legitimized and managed from economic arguments, as if economics were an objective (non-political and non-normative) science and practice founded on technical and legal arguments, principles and practices. That is the basic condition to think on economy, according to systemic theories and their strong institutionalism. But that is the same condition and rule to think on political institutions' structures, problems and practices: even political institutions - as political parties, legislatives and courts - must obey an internal dynamic, procedures and actors which centralize and streamline the political-juridical constitution, grounding and legitimation in the name of all society and of its social subjects. In either cases (modern State and capitalist market are the central themes of analysis in the Habermas' theory of modernity), institutional dynamic, procedures, norms, practices and actors have centrality concerning institutional constitution, legitimation and evolution, in the sense that they are institutional procedures and actors who legitimize both the institutional constitution and the social evolution. As consequence, Habermas talks about an indirect political intervention in the market and a citizen without subject in politics as the basic principles to the understanding of the contemporary market (indirect political intervention) and of the institutional politics (citizen without subject) (see HABERMAS, 2003b, p. 24, p. 147-148). 
What these two concepts signify? They signify the fact that we must abandon a direct political praxis concerning market's and State's constitution, legitimation and evolution, taking seriously their systemic programming and functioning as the basic starting point of the theoretical-political considerations - a contemporary radical politics begins from here and its fundamental sense and dynamic is dependent of that systemic institutional assumption. Indeed, the consequence of the Habermasian systemic understanding of capitalist market and modern State is their closure in relation to a democratic political praxis based on a general conception of social normativity which can ensemble and then determine priority market constitution and political legitimation. Systemic theory and systemic institutional constitution, legitimation and evolution are opposed to a general conception of social normativity and to an inclusive democratic political praxis which substitute technical and logical arguments, procedures and legal staff by normative-political arguments, considerations, procedures and common people (as social movements and citizen initiatives). Systemic institutions are streamlined only by internal procedures and actors, and determined basically by their internal self-referential and self-subsisting logic - so, their legitimation is fundamentally internal and based on internal necessities, instruments and procedures, then social normativity and democratic political praxis have no place in these systemic institutions.

What remains to the democratic political praxis in systemic theories? To live in the shadows of institutions and their systemic dynamic of constitution and legitimation; to have a representative and merely ornamental role in a double sense: social normativity and an inclusive democratic political praxis are politically peripheral concerning systemic institutions, their technical-logical constitution, legitimation and evolution; social movements and citizen initiatives have a peripheral political role concerning self-authorized and legal institutional technicians and political-economic elites. Now, a double problematic consequence regarding systemic institutions and their relations with the civil society emerges from the double condition mentioned above: systemic institutions are basically a technical and legal set of norms, practices, procedures and specialized staff which have a depoliticized and non-normative constitution, legitimation and evolution, because of their self-referential and self-subsisting understanding; systemic institutions are strongly opposed to social normativity and to democratic political praxis, due to their technical-legal constitution, which cannot be substituted nor by normative claims and principles, nor by political action and political subjects. So what remains to a radical democratic political praxis based on a notion of social normativity is the representative politics, determined by the strong institutionalism, i.e. the centralization and the monopolization of institutional and social legitimation and evolution by the very own systemic institutions (capitalist market and bureaucratic modern State) and their elites. In other terms, systemic institutions are non-normative and depoliticized with respect to their constitution, legitimation and evolution, denying as consequence the normative-political consideration on that institutional structuration and legitimation - that is the reason why they are strongly opposed to social normativity and to democratic political praxis.

\section{STRONG INSTITUTIONALISM, PROCEDURALISM AND POLITICAL PRAXIS}

Jürgen Habermas political-juridical procedural paradigm is a symptom of his dual theory of modernity: nor liberal (little politicized), nor republican (super politicized), but institutionalist. In other terms, Habermasian political-juridical paradigm leads to a strong institutionalism because of the centrality of the political-juridical institutions concerning the legitimation of the political praxis and of the social evolution. Habermas understands the liberal political-juridical paradigm as based on negative liberties 
and on the economic self-referentiality and self-subsistence regarding social normativity and political praxis. According to such liberal paradigm, each social system and particularly the economic field have a very specific dynamic which must be respected from alien interventions, principles and actors. So the very fundamental sense of the politics is to protect that institutional systemic self-referentiality and self-subsistence (laissez-faire accessed and determined only by individual meritocracy which leads to a minimal politics). What matters, in the liberal political theory, is the institutional field, its structuration, norms, practices and actors - and they are beyond a general notion of social normativity and of a radical democratic political praxis - in this sense, the market only can be accessed by laissez-faire and meritocracy (see HABERMAS, 2003a, p. 305-306, p. 325-326, p. 335-337). On the other hand, republican political-juridical paradigm emphasizes a direct and inclusive democratic political praxis as the basic motto to the social transformation and to the institutional constitution, legitimation and evolution. A republican paradigm denies, therefore, the systemic differentiation and autonomy concerning the social normativity and democratic political praxis, as well as the liberal's negative and minimal politics. Here, there is not a separation between systemic institutional organization and normative-political praxis, in the sense that institutions are not objective, neutral and impartial worlds, as well as they have basically a political structuration which is resulted from conflicting social classes, their struggles and political hegemony. So according to the republican paradigm, institutions have a secondary political role in relation to a radical democratic political praxis, becoming subordinated to it: what matters are the political subjects and the social struggles - the political in its effective praxis, the politics as social praxis (see HABERMAS, 2003a, p. 331-332).

The liberal paradigm is wrong, according to Habermas, because of the fact that the problem to economic stability and evolution is not the political institutions and the social rights. Capitalist market represents also a great challenge to democratic political organization based on a notion of social justice. Social justice is not a mirage, as said Friedrich Hayek (father of neoliberalism), but a social necessity, founded on a notion of social normativity and performed politically. So liberal economicism regarding political institutions and social constitution is partial, because it does not take seriously the dangerous social and political effects of the economic inequalities, of the concentration of income and of the market's instability (see HABERMAS, 2003a, p. 326). We cannot abandon political intervention and reparation (even if it is an indirect political intervention) - political institutions stabilize market dynamic. Republican paradigm is wrong in the moment that it centralizes political praxis in the civil society's political subjects, refusing the political-normative centrality of the institutions (see HABERMAS, 1998, p. 14-21; 2003b, p. 145-146). Why such republican political comprehension is incorrect or partial? Because of the fact that it minimizes the institutional importance regarding the orientation and structuration of the social dynamic, something that civil society's political subjects cannot do and guarantee (see HABERMAS, 2003a, p. 290; 2003b, p. 21). A direct and radical political democracy is no longer possible today (if it signifies the centrality of civil society's political subjects and the peripheral political-normative role of the political-juridical institutions), for there are no more social super-subjects as social classes, so social normativity is guarded, fomented and streamlined preponderantly by political-juridical institutions. The same way, a radical political praxis into the social systems, which intends to substitute money and bureaucratic power for social normativity and politics, is not possible, because of the institutions' systemic constitution, which makes them self-referential, self-subsisting and closed to political praxis and social normativity - their technical-logical legitimation and functioning must be strictly respected. The republicanism erases and forgets the technical-logical character of the institutions or social systems, and that cannot be done in the contemporary societies. 
Now, which is the political-juridical procedural paradigm's specificity in relation to the liberal and republican paradigms? It is the fact that the procedural paradigm does not accept the liberal argument of a problem concerning political intervention on the market and the social rights as basis of a democratic politics. Laissez-faire and meritocracy are not sufficient to stabilize a democratic society, which means that politics is absolutely important to it. In the same way, the procedural paradigm does not accept the republican strong emphasis on the civil society's political subjects and their radical democratic political praxis, as well as the republican minimization of the institutional political-normative role (in relation to a democratic political praxis rooted on civil society's spontaneity) (see HABERMAS, 2003b, p. 138-139). Currently, it is not possible to minimize the political-normative role of the political-juridical institutions, because of the decadence of leftist theories based on a totalizing comprehension of the society, its spheres and political subjects. Marxist theorethical-political categories - such as social classes, class struggles, and even the idea of society as a self-consciousness totality whose center would be constituted by economic life - are not valid today for the understanding of the democratic social and institutional dynamic and praxis (see HABERMAS, 2003a, p. 83, p. 111; 1997, p. 133-134). An emancipatory political theory must have another theoretical and normative basis, and that is the case of the Habermasian procedural juridical-political paradigm.

Habermasian political-juridical procedural paradigm is constituted by three interdependent ideas: society is not a totality, but divided in closed and particularized social systems; there are no more social super-subjects, but only individual political subjects; political-juridical institutions - conceived in a systemic way - guard and foment social normativity (see HABERMAS, 2003a, p. 20; 2003b, p. 24, p. 72). Now, contemporary societies are complex societies, i.e. very differentiated both in terms of individualization of the social-political subjects and regarding the consolidation of different and particular social systems (see HABERMAS, 2003a, p. 17-18). There is no more a very strong identity and equality (cultural, political, economic etc.) between individuals, which means an individualization of social-political actors; and the society is not anymore a cultural-political core founded on a common center which gives all orientations and rules to socialization and individualization at all. So the current societies' very important characteristic is their cultural-political individualization (particular social-political actors with no identity one each other) and the consolidation of different and conflicting social systems or institutions which have a very proper logic of programming and functioning. As consequence, there are not social classes as super-subjects, but only individual social-political subjects. So an emancipatory utopia founded on the revolutionary vocation and role of specific social classes is delegitimized as a theoretical-political alternative, in the same way that those social classes do not represent anymore an objective notion of social normativity in the name of all society. On the other hand, contemporary political praxis must start from the fact that society is not anymore a homogeneous institutional totality, in the sense that there is not anymore a common institutional core from which all society is streamlined. So also here a political utopia cannot presuppose that the social transformation is possible by the reconstruction of society's central core: a radical political praxis has no more sense if it is based on such notion of society as a totality with a central political or economic core (as marxism does).

Contemporary political theory and praxis must start from the fact that current societies are marked by the consolidation of different and autonomous systemic institutions, in that each field of social reproduction is particular, self-referential and self-subsisting in relation to other fields (for example: economy is different of State, and vice versa; both are different of the social normativity; all the three have particular logics of programming and functioning). In a such situation, a social transformation is 
always particularized (society is not a totality, but divided in different and autonomous social systems); it has not anymore totalizing range and effects, as well as it cannot intend to change all social systems (social systems which works only by their exclusive internal logic and dynamic). In other terms, political praxis is not anymore the central - the only central - core of the society; and it is not anymore the fundamental instrument from which society (as self-conscious totality) transforms itself along the time (see HABERMAS, 2003b, p. 25). A society divided in self-subsisting and self-referential social systems has many centers of power, each one of them with particular and closed logics of programming and functioning. Political praxis and political institutions are still important, but not central, as their political-normative-bureaucratic dynamics also are important, but they cannot substitute systemic institutional logics and dynamics (which are always self-referential and self-subsisting).

So here appears a Habermasian procedural paradigm's double starting point or presupposition, namely: society is not a totality, but divided in many different and closed social systems; and there are not anymore social classes as political super-subjects. Now, a double problematic consequence (which was generated also by Habermasian theory of modernity and its separation between system and lifeworld, each one with particular and irreconcilable logics and dynamics) emerges from such double starting point: the systemic institutional centrality concerning the constitution, legitimation and evolution of each social field represented by its specific and related systemic institution; and the centralization and monopolization of the social normativity by political institutions which generates a strong institutionalism as basis to institutional and social grounding and evolution. Indeed, also in the Habermasian political-juridical procedural paradigm, the systemic theory gives the theoretical basis to the understanding of contemporary complex societies, in the sense that our current societies are based on systemic autonomization and self-referentiality - and dependent of such systemic organization. So Habermas adopts the systemic institutional constitution as a natural fact and point of starting to the comprehension, constitution and legitimation of the modern societies. He does not problematize such systemic approach as a liberal presupposition concerning modernity's understanding and legitimation. That is his non-critic assumption; it is simply his starting point, and Habermas does not criticize it in any moment - contrarily to his critic against Marxist politicization of the social systems. According to Habermas, social systems or institutions, the moment they centralize and monopolize the legitimation and evolution of specific social fields, have a technical constitution, not a direct political and normative structuration and legitimation.

Therefore, the first problematic consequence of the Habermasian procedural paradigm, based on systemic institutional autonomization, is the very depoliticization of systemic institutional logic and dynamic, which become closed, self-referential and self-subsisting regarding to social normativity and to democratic political praxis, acquiring a technical-logical constitution and legitimation (see FORBATH, 1998, p. 272-286; WHITE, 1995, p. 133-136). Such liberal notion of modernization can always affirm itself as a technical and logical organization, as a non-normative and non-political instance. In that case, it organizes and evolves itself as a particular logic and dynamic which is separated and made independent concerning normative claims and political praxis. Indeed, liberal comprehension of modernity (such as Friedrich Hayek, Milton Friedman and Robert Nozick) argues in favor of the market's self-referentiality and self-subsistence in relation to social normativity and political praxis, in that its constitution, legitimation and evolution is dependent of political institutions and social normativity only in an indirect way, as well as market's logic and dynamic generate and determine social evolution or social-cultural consequences only in an indirect way. There is not, according to 
those liberal political theories, a direct linking between very different systems as market, State and civil society: each one functions in a specific way, and that is the starting point to the understanding and legitimation of the market's constitution and grounding. That is the reason why Friedrich Hayek says that social justice is a mirage: it presupposes a normative-political constitution of the market, as it affirms a linking among social, political and economic fields, denying economy's systemic self-referentiality and self-subsistence, which is non-normative and non-political, just technical (laissez-faire and meritocracy). Of course, Habermas is not a conservative liberal; he argues against the return to a conservative liberal theory (such as neoliberalism), as he argues on theoretical-political failures of the neoliberalism (see HABERMAS, 2003a, p. 119). But his presupposition of the systemic institutional autonomization as the theoretical-political basis to the understanding and legitimation of the Western modernization leads directly or indirectly to the systemic institutional depoliticization and non-normative systemic structuration, i.e. to the systemic institutional closure regarding social normativity and democratic political praxis. As consequence, the systemic theory conceives the institutions as a very closed, nonpolitical, non-normative, technical and logical set of norms, practices, rules and actors, beyond civil society's political-normative control and influence.

The second problematic consequence of the Habermasian procedural paradigm is what I call of strong institutionalism regarding the constitution and legitimation of the political institutions. With the concept of strong institutionalism I understand the centralization and the monopolization of the social normativity by political institutions based on a systemic comprehension of its logic, dynamic, procedures and actors. Indeed, the Habermasian refusal to conceive social classes as political super-subjects leads to the concomitant refusal to link social subjects and social normativity. Here emerges the meaning of two concepts used by Habermas to signify the contemporary political specificity of democratic foundations. The first is the concept of law as medium between system and lifeworld (see HABERMAS, 2003a, p. 61-62, p. 82). It means that political-juridical institutions assume the role of normative political-juridical tribunal concerning normative social claims directed to the systemic institutions: those political-juridical institutions must decide if the normative social claims are justified and even in which sense they must be focused on the institutional systemic structuration. In other words, the very own political-juridical institutions (based on a systemic self-comprehension and limited by systemic structuration of the other institutions) decide about the legitimity of the social claims directed to the institutions themselves. The second is the consequent concept of citizenship without subject, which means that the institutions assume the guard, foment and fostering of the social normativity, substituting the current nonexistent social classes (see HABERMAS, 2003b, p. 24). In a such case, the Habermas' refusal of social classes as political super-subjects implies directly in the individualization of the civil society's political subjects, and that means the correlative Habermasian refusal of the fact that a specific social class represents the very own social normativity.

In contemporary societies, no social class has the capacity to represent all society and even to frame all social systems. Now, the social normativity, in the moment that it is not anymore centralized and streamlined by social classes, is assumed and centralized into political-juridical institutions - of course, individual social subjects can assume normative contents and submit normative claims to institutional validation, but the institutions are the center and the normative-political basis to judge and legitimate such social matters, vindications and actors. The political-juridical institutions link system and lifeworld, centralizing and monopolizing the last world on the social claims, but the systemic constitution and legitimation are strongly autonomous of the political and juridical interventions and 
controls - their systemic constitution and legitimation, which is non-normative and non-political, deny a direct juridical-political intervention. Therefore, both the systemic institutional legitimation and the democratic centrality of the political-juridical institutions minimize the social movement's political role, depoliticizing highly the institutional constitution, validation and evolution. Institutions (political and economic institutions) become the very center of their own legitimation and evolution along the time. Social movements and citizen initiatives assume also a political-normative role, but they do not substitute the normative centrality of the political-juridical institutions, nor can intervene directly in the systemic institutional constitution and legitimation - the social movements' political role is peripheral in relation to the systemic institutional constitution, legitimation and evolution, so the political-juridical center is constituted by the juridical-political institutions' internal dynamic, procedures and legal staff, as of the social systems as a self-referential instances at all (here the social movements' political role is denied by the market's technical-logical internal constitution and legitimation).

So the Habermasian political-juridical procedural paradigm has as central normative basis the fact that institutions represent the basic core of a democratic society, as they assume and establish from internally the procedures, norms, practices and authorized actors which perform institutional constitution and evolution along the time. Now, institutions - with their procedures, norms and actors - represent all society and civil society's political subjects. Of course, political-juridical institutions are based on an intersection between formal and informal public spheres, formal and informal political subjects, and formal and informal political praxis. Such dialectics between formal and informal politics is the condition, as Habermas said, to the democratic legitimation and evolution, i.e. institutions are not sufficient to a complete democracy; they require the social participation (see HABERMAS, 2003b, p. 34, p. 104). However, those two characteristics mentioned above - modernization as systemic self-differentiation and autonomy; institutional centralization and monopolization of the social normativity - lead both to the impossibility of a radical politics directed to the economic field, and to the strong institutionalism regarding the political legitimation and performing. On the one hand, democratic politics cannot substitute systemic logic and dynamic concerning institutional constitution, legitimation and evolution; on the other hand, social movements and citizen initiatives (as informal political praxis) cannot substitute institutional procedures, arenas and legal actors, because of the fact that institutions constitute the fundamental core of democracy. So, how the civil society can face social systems' overwhelming totalization in relation to normative social reproduction? It cannot substitute systemic logic and dynamic by normative foundations; it cannot substitute formal spheres by informal spheres; as it cannot substitute political parties by social movements and citizen initiatives.

Habermas tries to avoid such problem of a strong institutionalism through the affirmation that a mature democratic culture (an effective informal democratic praxis, with informal arenas and political subjects) is the normative-political condition both to the institutionalism and to a radical democratic political praxis, in that social movements and citizen initiatives could prevent institutional corruption, autonomy and bureaucratization; they could also formulate political proposals and make political pressure against institutionalism, when it is incorrect (see HABERMAS, 2003b, p. 33, p. 58, p. 90-92). But here emerges two problems: first, the informal political praxis does not assume an institutional role, as informal political subjects cannot substitute formal political subjects, and only the institutions - according to their internal procedures, norms and actors - decide on the legitimation of normative claims and social evolution; second, a mature democratic culture is forged by social struggles which confront the political structuration and evolution of the institutions, denying a systemic institutional 
comprehension as the basis of a democratic society. In that last case, a mature democratic culture emerges only by substituting institutions' systemic self-referentiality, self-subsistence and autonomy concerning normative foundations and democratic political praxis by a direct and inclusive democratic political praxis into social systems. So if a democratic culture is the normative-political condition to systemic institutions and even to avoid or to minimize the strong institutionalism, then such institutions have not a self-referential structuration and legitimation, nor a technical-logical programming and functioning, as they cannot substitute informal arenas and political subjects, centralizing and monopolizing both the social normativity and the political legitimation of the social evolution. It signifies the politicization of the institutional systemic structuration, legitimation and evolution, in the sense that institutions become a political-normative matter and, then, getting directly accessed by an inclusive democratic political praxis based on a notion of social normativity - here, a representative politics and a systemic institutional autonomy are not sufficient or valid to the constitution, legitimation and evolution of the democratic society.

\section{ANOTHER WAY TO A RADICAL DEMOCRATIC POLITICS: SOME CONCLUSIONS}

In that paper, Jürgen Habermas' theory of modernity has furnished to us normative-political arguments to think contemporary democratic constitution and legitimation. Habermas has three important arguments concerning current democratic societies: such societies are based on institutions' systemic self-differentiation, self-referentiality and autonomization regarding social normativity and democratic political praxis; politics is no longer the center of the society, because of the societal division in closed and particular social systems; and political-juridical institutions become the basic core of a democratic society, centralizing and monopolizing both the grounding and the foment of the social normativity, and the legitimation of the social evolution. These three arguments lead to the strong institutionalism regarding both to the systemic institutional comprehension and to the political praxis. Here, a direct radical political praxis from civil society's political subjects is delegitimized by the fact that political institutions, as economic institutions, have procedural, impartial, neutral and formal dynamic, norms and actors which assume the guard, the legitimation and the performing of social normativity, substituting informal democratic politics, arenas and subjects by the centrality of the formal politics, arenas and actors. Besides, a radical and inclusive democratic political praxis is also delegitimized by the systemic institutional structuration and legitimation, whose constitution is non-political and non-normative.

Now, what remains for facing the modernization's pathologies is the representative politics as the only way to a contemporary democracy - which is based on such process of modernization - evolve and legitimize itself over time. On the one hand, systemic institutional constitution cannot be substituted by democratic political praxis and social normativity - it depends of a formal and technical organization which is self-referential and self-subsisting in relation to politics and social normativity. On the other hand, politics and political institutions are not already the center of a contemporary society based on the social-economic modernization. Politics and political institutions represent a particular field and praxis, existing side by side with other social systems - what means many particular logics of programming and functioning living side by side with each other and competing between them for hegemony (see HABERMAS, 2003b, p. 25). Representative politics is all which remains as democratic political praxis exactly by the fact that systemic institutions are closed to politics and social normativity, as strong institutionalism in politics is closed to informal spheres, arenas and political actors. Habermas said 
that contemporary social movements must renounce to the utopia of a society which is self-organized in its totality, so the political praxis cannot substitute or intervene in all systemic institutional logics and dynamics (see HABERMAS, 2003b, p. 105-106). It does not mean that democratic political praxis loses its importance as one form of social organization, but it is limited by systemic logics and dynamics. However, the starting points of the habermasian theory of modernity - systemic institutional autonomization and strong political institutionalism - lead to the systemic depoliticization and therefore to the severe weakening of the democratic political praxis, which become peripheral regarding both systemic autonomization and the institutions' centralization of the political legitimation.

That is the reason why Jürgen Habermas' theory of modernity and its consequent political-juridical procedural paradigm cannot interpret correctly nor solve effectively a contemporary very dangerous political problem, namely: the profound imbrication among political parties, economic oligarchies and strong institutionalism founded on a systemic comprehension of institutional constitution, legitimation and evolution. Such theory of modernity cannot face that problem because of the fact that it depoliticizes the systemic institutional constitution in the moment that it assumes systemic theory as basis to the understanding of the Western modernization and of the current democratic societies' political-institutional conditions. In a such case, the correlation between formal spheres, procedures, arenas and actors with informal spheres, procedures, arenas and actors is not sufficient to frame systemic institutional autonomization and closure regarding to normative claims and to an inclusive democratic political praxis. Systemic institutional logic and dynamic can always appeal to their specificity and particularity concerning their own constitution and legitimation, becoming highly a depoliticized and non-normative field.

Besides, social normativity and democratic political praxis are centralized and monopolized from a kind of strong institutionalism, which means that informal spheres, procedures, arenas and actors have a secondary and peripheral role in relation to juridical-political institutions (and to juridical-political institutions conceived in a systemic way and sense). Indeed, what matters to the Habermasian political-juridical procedural paradigm is, in first place, the political-juridical institutions - their internal norms, practices, procedures and actors - as basis of a democratic constitution, legitimation and evolution along the time. A society based on the consolidated individualization of the political subjects cannot base its normative constitution and legitimation on a particular and specific social subject; it must base its political stability, as its normative-administrative legitimation, on the very own political-juridical institutions which establish an arena, procedures, norms, practices and authorized actors as normative-political keys to the social evolution's legitimation. Now, as I said before, Habermas institutes two conditions of such kind of political-juridical institutionalism: first, as commented above, it is not the center of a contemporary society based on the process of Western modernization, so it must live side by side with other social systems, each one of them with a very self-referential and closed logic of programming and functioning; second, it is necessary a mature democratic culture as the institutions' normative basis. In the first case, political institutions are limited by institutions' systemic logic and dynamic; in the second case (and that is very interesting) a mature democratic culture is the condition sine qua non to the political-juridical procedural paradigm - without that mature democratic culture, institutionalism itself does not guarantee its capability to centralize and monopolize both the social normativity and the social evolution's legitimation in an impartial, neutral and publicized way. 
Now, what such condition means? It means that contrarily to what Habermas believes, the politicaljuridical institutions are not the central core of a democratic society, but the very own democratic culture, i.e. the formal arena, procedures, norms, practices and actors are not the key to the democratic stabilization and evolution, but the very own informal arenas, procedures, practices and social subjects. So a democratic culture grounds, generates and sustains democratic institutions, and not contrary. Again, what it means? It means that civil society's political subjects centralize and streamline the social normativity over social evolution and political institutional constitution, defining hegemonic ways, practices, codes and institutional designs which become the institutions themselves. They institute also a hegemonic comprehension of the social systems' political threatening. Both cases imply there is not a stylized process of modernization based on the systemic autonomization and self-differentiation, but it is the result of class hegemony or of political struggles from civil society's political subjects - the hegemonic comprehension of the process of modernization is a matter of social-political hegemony, not the natural fact of the modernization itself, as if modernization has an essence or if it were a direct, pure and homogenous way. The same way, democratic politics, the moment it is the condition to institutionalism, puts down the Habermasian political-juridical proceduralism's basic idea, i.e. the centralization and monopolization of the social normativity by political-juridical institutions, as it puts down both the closed institutional logic and dynamic, and the representative politics. Informal arenas, practices and social subjects become the very political praxis and subjects in relation to systemic institutional constitution and legitimation.

Such finding (the centrality of civil society's arena, practices and political subjects) enables the politicization of the social systems' constitution and legitimation, as the overthrow of the systemic closure and autonomization concerning to social normativity and to an inclusive democratic political praxis. In a double sense the systemic institutional constitution and the strong institutionalism are inserted in and dependent of the social normativity: social reproduction is a normative praxis and has basically normative foundations; and democratic politics is grounded on and streamlined by civil society's political praxis, cultural constitution and social subjects. Therefore systemic institutional legitimation is always a political and normative matter, made only by an inclusive democratic political praxis. There are not a separation and a conflict between system and lifeworld, but rather social struggles between social classes which institute a hegemonic political, normative and economic comprehension socially biding. There is no such thing like a technical and logical systemic institution, but the strict political-normative institutional constitution and legitimation which is a result of the social-political hegemony. So the hegemonic theoretical-political institutional conception is always generated and defined by social struggles between social classes or social super-subjects. Besides, systemic institutional logic has basically general role and effects, and it means that it cannot be conceived as a particular logic and dynamic with short range consequences. Systemic institutional logic and dynamic have macro consequences, i.e. political and normative consequences regarding to political institutional legitimation and to social evolution. So systemic institutional logic and dynamic cannot be separated as a particular and independent field of the political praxis and of the social normativity, which means their depoliticization and non-normative structuration. Contrarily to that, systemic logic and dynamic are political and have normative constitution, legitimation and evolution, as political and normative effects (see PIKETTY, 2014; WOLFE, 2009, 1980; ARBLASTER, 1984).

Democratic political praxis emerges beyond systemic theory and strong institutionalism, because it is raised on the civil society's political subjects and social struggles - it is defined by them, it is streamlined 
by the hegemonic political forces and their counterpoints. Systemic theory and strong institutionalism deny such political constitution and dynamic, as they depoliticize the systemic institutional structuration, legitimation and evolution. That depoliticization implies in the systemic institutional autonomy and self-referentiality concerning an inclusive and direct democratic political praxis, as well as in the centralization and monopolization of the social normativity and of the political dynamic by the very own social systems and political institutions. Here, as I said above, only the representative politics based on political parties have legitimity to perform institutional mechanisms and social evolution. Besides, as capitalist market - and it is the more important political-normative concern and social-political structure even in contemporary times! - is defined by systemic structuration and legitimation, it is also depoliticized regarding democratic political praxis. In consequence, it is not a normative field and has not a political-normative dynamic. So, capitalist market becomes a matter of economic elites and their technicians (because of the fact that it is a technical and logical field) with very particular, closed, self-referential and self-subsisting logic, dynamic, procedures and actors.

Here emerges in a double sense the intrinsic linking among strong institutionalism, political parties and economic oligarchies. First, systemic institutions only admit their specific and self-referential logic, dynamic, procedures and legal actors, becoming closed to an inclusive democratic political praxis and to normative claims; second, formal politics (institutional politics and political parties) become very dependent of the economic dynamic, logic and elites, by the fact that politics - which intends to perform a macro social action - always must legitimize both the institutional proceduralism and the social evolution according to the market as a system that is central regarding the social constitution and the political institutional structuration (there is also the private funding of the political parties, of course, as another problem for contemporary democratic politics - it leads to the profound intersection between political parties and economic elites too). But how the capitalist market is central to political institutional structuration and to social evolution? It is central to politics in the sense that it cannot be violated in its closed and self-referential logic and dynamic, as it imposes its systemic organization and legitimation to political institutions. So, such political institutions must respect market autonomy, self-referentiality and self-subsistence (and even acquiring market dynamic and logic into political structuration and legitimation), as they must perform politically the market conditions of reproduction, i.e. the framing of the lifeworld or civil society (and even the natural environment!) according to market logic and dynamic. That is the double sense of the intrinsic and nefarious linking among strong institutionalism (based on systemic institutional logic and dynamic), political parties and economic elites: such linking both empowers systemic institutional autonomy, closure, self-referentiality and self-subsistence regarding to politics and to social normativity, and depoliticizes institutional constitution and legitimation, submitting the social reproduction to the systemic institutional logic and dynamic.

Now, how an alternative political praxis can face such linking? First, it can start by inverting the political centrality of the systemic political institutions concerning informal arenas, practices and social actors, i.e. an alternative and informal political praxis must affirms itself as the basis to the institutional structuration, legitimation and evolution, and not contrary. Second, that implies in the politicization of the strong institutionalism based on systemic logic and dynamic. It is necessary, here, that civil society can deny political institutional self-referentiality and closure in relation to social subjects and to normative claims, which means that political institutions must share powers, arenas, practices and process of legitimation with the social subjects. So, in that case informal arenas, practices and social subjects assume a political role which is characterized by the substitution of the very own 
formal institutions and political actors. The strong institutionalism depoliticizes social evolution and economic constitution, so informal politics and social subjects must politicize again the social evolution and economic constitution, politicizing also the political-juridical institutions and refusing their impartiality and neutrality as basis of contemporary politics: contemporary politics is a social struggle, not an impartial and neutral institutional proceduralism based on systemic institutional logic and dynamic. Third, an alternative political praxis must deconstruct the traditional naturalization of the process of Western modernization, i.e. a radical democratic political praxis cannot be based on the notion of Western modernization as systemic autonomization, self-referentiality and self-subsistence regarding political institutions, social evolution and normative claims.

There is not such separation between systemic institutions and lifeworld, between a logical dynamic and a normative-political dynamic; and there is not a systemic institutional closure, autonomy, self-referentiality and self-subsistence regarding political praxis and social normativity. That hegemonic comprehension of the Western modernization is resulted from a liberal comprehension of it, not a natural or general or objective process of modernization at all - it is a political comprehension, not an essential or metaphysic comprehension, nor a technical-logical comprehension. Liberal's comprehension of the Western modernization has as central argument the systemic differentiation and depoliticization (laissez-faire), and that is the basis of the hegemonic liberal comprehension of Western modernization which is assumed even by contemporary left (as I have argued on Habermas' theory of modernity, but it can be perceived also in the Giddens' work). Such deconstruction allows the politicization of the Western modernization and as consequence its framing by an inclusive democratic political praxis founded on a notion of social normativity. Here, the profound imbrication among economy, politics and social evolution leads to the politicization both of that linking and of the particular constitution (which is political and normative) of each social system. So the systemic institutional politicization avoids systemic institutional self-referentiality, neutrality and impartiality concerning democratic politics and social normativity, as it puts the civil society's political dynamic, subjects and struggles as the basic motto to the political hegemony. Above all, the politicization both of the systemic institutional dynamic and of the strong institutionalism shows that society is a political-normative totality with imbricated institutions and social subjects, i.e. it shows that all is politics and political - that is the starting point to a contemporary emancipatory and inclusive democratic political praxis.

\section{REFERENCES}

ARBLASTER, A. 1984. The rise and decline of western liberalism. Oxford: Basic Blackwell.

FORBATH, W.E. 1998. Short-circuit: a critic of Habermas' understanding of law, politics, and economic life. In: ROSENFELD, M.; ARATO, A. (Eds.). Habermas on law and democracy: critical exchanges. Los Angeles: University of California Press. p. 272-286.

GIDDENS, A. 1996. Para além da esquerda e da direita: o futuro da política radical. Tradução de Alvaro Hattnher. São Paulo: Editora da UNESP.

. 2000. A terceira via: reflexões sobre o impasse da social-democracia. Tradução de Maria Luiza X. de A. Borges. Rio de Janeiro: Record. 
.2001. A terceira via e seus críticos. Tradução de Ryta Vinagre. Rio de Janeiro: Record.

HABERMAS, J. 1990. Para a reconstrução do materialismo histórico. Tradução de Carlos Nelson Coutinho. São Paulo: Brasiliense.

. 1997. Ensayos políticos. Traducción de Ramón Garcia Cotarelo. Barcelona: Ediciones Península.

1998. Paradigms of law. In: ROSENFELD, M.; ARATO, A. (Eds.). Habermas on law and democracy: critical exchanges. Los Angeles: University of California Press. p. 13-25

. 1999. Problemas de legitimación en el capitalismo tardio. Traducción de José Luis Etcheverry. Madrid: Ediciones Cátedra.

.2003a. Direito e democracia: entre facticidade e validade. Tradução de Flávio Beno Siebeneichler. Rio de Janeiro: Tempo Brasileiro. v. 1.

.2003b. Direito e democracia: entre facticidade e validade. Tradução de Flávio Beno Siebeneichler. Rio de Janeiro: Tempo Brasileiro. v. 2.

. 2012a. Teoria da ação comunicativa: racionalidade da ação e racionalização social. Tradução de Paulo Astor Soethe. São Paulo: Martins Fontes. v. 1.

. 2012b. Teoria da ação comunicativa: sobre a crítica da razão funcionalista. Tradução de Flávio Beno Siebeneichler. São Paulo: Martins Fontes. v. 2.

HAYEK, F. A. 1987. O caminho de servidão. Tradução de Ana Maria Capovilla et al. Rio de Janeiro: Instituto Liberal.

. 1995. Arrogância fatal: os erros do socialismo. Tradução de Ana Maria Capovilla e Candido Mendes Prunes. Porto Alegre: Ortiz Editores.

NOZICK, R. 1991. Anarquia, Estado e utopia. Tradução de Raul Jungmann. Rio de Janeiro: Jorge Zahar.

PARSONS, T. 2010a. A estrutura da ação social: um estudo de teoria social com especial referência a um grupo de autores europeus recentes. Tradução de Vera Joscelyne. Petrópolis: Vozes. v. 1.

.2010b. A estrutura da ação social: um estudo de teoria social com especial referência a um grupo de autores europeus recentes. Tradução de Raquel Weiss. Petrópolis: Vozes. v. 2.

PIKETTY, T. 2014. O capital no século XXI. Tradução de Monica Baumgarten de Bolle. Rio de Janeiro: Intrínseca.

WEBER, M. 1984. Ensayos sobre sociología de la religión (T. I). Traducción de José Almaraz y Julio Carabaña. Madrid: Taurus.

1992. Economia y sociedad: esbozo de sociología comprensiva. Traducción de José Medina Echavarria et al. México: Fóndo de Cultura Económica. 
WHITE, S. K. 1995. Razão, justiça e modernidade: a obra recente de Jürgen Habermas. Tradução de Márcio Pugliesi. São Paulo: Ícone.

WOLFE, A. 2009. The future of liberalism. New York: Alfred A. Knopf.

1980. Los límites de la legitimidad: contradicciones del capitalismo contemporáneo. Madrid: Siglo Veintiuno Editores. 